\title{
ANALISIS TINGKAT KEPUASAN PENGGUNA SISTEM INFORMASI PERPUSTAKAAN MENGGUNAKAN PIECES FRAMEWORK
}

\author{
Indrawati Indrawati ${ }^{1}$, Poetri Lestari Lokapitasari Belluano ${ }^{2}$, Harlinda Harlinda ${ }^{3}$, \\ Fatima A.R Tuasamu ${ }^{4}$, Dirgahayu Lantara ${ }^{5}$ \\ inndrawatii011@gmail.com¹, poetrilestari@umi.ac.id², harlinda@umi.ac.id² \\ imharachman71@gmail.com ${ }^{4}$, dirga_lantara@yahoo.com ${ }^{5}$ \\ 1,2,3,4Universitas Muslim Indonesia
}

\begin{abstract}
Abstrak
Penggunaan sistem informasi memerlukan pengaturan dan pengelolaan yang bersifat khusus, sehingga sistem ini biasa disebut sebagai sistem informasi manajemen. Didalamnya terdapat berbagai kegiatan mulai dari perencanaan sistem, perawatan, sampai pengukuran kinerjanya. Dalam menjalankan sistem informasi perpustakaan diperlukan perangkat lunak dan perangkat keras serta manusia sebagai operatornya. Komponen diatas harus menjadi kegiatan yang saling berhubungan sehingga perpustakaan dapat berjalan dengan lancar. Untuk menentukan apakah komponen dari sistem informasi berjalan dengan baik maka memerlukan proses evaluasi. Tujuan dari penelitian ini adalah untuk mengukur tingkat kepuasan pengguna sistem dan untuk mengetahui kekuatan dan kelemahan sistem dalam penggunaan sistem informasi perpustakaan. Metode yang digunakan adalah metode analisis PIECES Framework, yang terdiri dari beberapa point analisa, yaitu: Performance, Informations and Data, Economics, Control and Security, Efficiency, dan Service. Dimana setiap poin analisa merupakan referensi evaluasi dan analisa sistem informasi. Hasil penelitian ini berupa aplikasi web yang mampu menganalisa tingkat kepuasan pengguna terhadap sistem informasi perpustakaan menggunakan metode analisis PIECES Framework dan dilengkapi dengan grafik pelaporan tingkat kepuasan dari sistem yang diukur pada periode tahun 2018.
\end{abstract}

Kata kunci: Analisis, Kepuasan, Pengguna, Sistem Informasi Perpustakaan, PIECES Framework

Abstract

The use of information systems requires special management and management, so this system is commonly referred to as a management information system. In it there are various activities ranging from system planning, maintenance, to measuring performance. In running a library information system, software and hardware are needed as well as humans as operators. The above components must be activities that are interconnected so that the library can run smoothly. To determine whether the components of the information system are running well, it requires an evaluation process. The purpose of this study is to measure the level of satisfaction of system users and to determine the strengths and weaknesses of the system in the use of library information systems. The method used is the analytical method PIECES Framework, which consists of several points of analysis, namely: Performance, Information and Data, Economics, Control and Security, Efficiency, and Service. Where each analysis point is a reference for evaluation and analysis of information systems. The results of this study are web applications that are able to analyze the level of user satisfaction with the library information system using the PIECES Framework analysis method and equipped with a satisfaction level reporting chart of the system measured in the 2018 period.

Keywords: Analysis, Satisfaction, Users, Library Information Systems, PIECES Framework

\section{Pendahuluan}

Peranan sistem informasi dalam berbagai bidang usaha sudah menjadi penopang dalam kegiatan operasional perusahaan sehari-hari, Salah satunya sistem informasi perpustakaan. Saat ini perpustakaan merupakan sebagai pusat informasi dan sumber ilmu pengetahuan. Sebagai pusat informasi, perpustakaan sudah diwajibkan untuk menggunakan sistem informasi untuk mengelola data dan informasi dalam kegiatan perpustakaan sehari-hari[1].

Perpustakaan Utsman Bin Affan Universitas Muslim Indonesia (UMI) dalam memberikan layanan sirkulasi, layanan referensi, pencetakan label dan pengarsipan data buku sudah menggunakan beberapa aplikasi yang berbasis komputer. Aplikasi tersebut antara lain seperti aplikasi peminjaman buku, aplikasi pengembalian buku, aplikasi katalog pencarian buku dan lain lain.

Penggunaan sistem informasi memerlukan pengaturan dan pengelolaan yang bersifat khusus, sehingga sistem ini biasa disebut sebagai sistem informasi manajemen. Didalamnya terdapat 
ILKOM Jurnal Ilmiah Volume 11 Nomor 2 Agustus 2019

Terakreditasi peringkat 3 SK. No. 28/E/KPT/2019

berbagai kegiatan mulai dari perencanaan sistem, perawatan, sampai pengukuran kinerjanya. Untuk mengetahui apakah komponen sistem informasi berjalan sebagaimana mestinya, mesti memerlukan proses evaluasi. Dalam penelitian ini dilakukan kegiatan evaluasi terhadap sebuah sistem informasi perpustakaan untuk menilai apakah sistem informasi perpustakaan yang digunakan sudah dapat memenuhi kebutuhan para penggunanya yaitu petugas perpustakaan dan anggota perpustakaan.

Dalam memberikan analisis atau evaluasi terhadap suatu sistem, dapat dilakukan dengan beberapa model analisis. Dalam penelitian ini, akan digunakan model analisis PIECES Framework. PIECES Framework sendiri merupakan suatu alat dalam menganalisis sistem informasi yang berbasis komputer, dimana terdiri dari point-point penting yang berguna untuk dijadikan pedoman / acuan dalam menganalisis sistem tersebut. Secara singkat, PIECES Framework mengandung hal-hal penting dalam pengevaluasian sistem, seperti: Performance, Information and data, Economics, Control and security, Efficiency, dan yang terakhir Service[2].

Dengan menggunakan PIECES sebagai alat analisis sistem, suatu sistem secara detail dan menyeluruh akan mendapat perhatian khusus, sehingga kekuatan dan kelemahan sistem dapat diketahui untuk nantinya dijadikan acuan bagi kemajuan perusahaan selanjutnya. Hal ini mendorong penulis untuk mengangkat judul "Analisis Tingkat Kepuasan Pengguna Sistem Informasi Perpustakaan Menggunakan PIECES Framework".

\section{Metode}

Jenis atau metode yang digunakan dalam penelitian ini adalah menggunakan metode kualitif dengan analisis data secara induktif. Alasan penggunaan analisis data secara induktif karena proses induktif dapat menemukan kenyataan-kenyataan jamak yang terdapat dalam data, selain itu analisis induktif dapat membuat hubungan peneliti dan responden menjadi eksplisit dan dapat dikenal[3].

\subsection{Pemilihan Sampel}

1. Populasi

Populasi adalah wilayah generalisasi yang terdiri atas obyek/subyek yang mempunyai kualitas dan karakteristik tertentu yang ditetapkan oleh peneliti untuk dipelajari dan kemudian ditarik kesimpulannya[4]. Populasi dalam penelitian ini yaitu petugas yang menggunakan sistem informasi perpustakaan yang terdiri dari 10 orang petugas perpustakaan dan 20 orang mahasiswa.

\section{Responden Penelitian}

Teknik pengambilan sampel yang digunakan adalah purposive sampling, dimana sampel dipilih oleh peneliti dalam penelitian ini adalah orang yang ahli dalam bidang tersebut. Teknik ini digunakan karena responden yang dipilih merupakan orang yang memang bergelut di bidangnya.

\subsection{Metode Pengumpulan Data}

1. Data Primer, merupakan data utama yang digunakan dalam penelitian yang diperoleh melalui observasi, wawancara dan survei. Data primer yang digunakan dalam penelitian ini bersumber dari petugas perpustakaan dan anggota perpustakaan yaitu berupa gambaran tentang sistem informasi perpustakaan dengan melakukan wawancara terhadap petugas perpustakaan, selain itu data tentang tingkat kepuasan petugas perpustakaan sebagai pengguna dari sistem informasi perpustakaan dengan memberikan daftar pernyataan berupa kuesioner[5].

2. Data Sekunder adalah data yang diperoleh peneliti secara tidak langsung yang berupa bukti, catatan atau laporan historis. Selain itu data sekunder yang digunakan diperoleh melalui literatur atau studi pustaka seperti buku, jurnal, prosiding dan laman. Selain itu penulis juga menggunakan dokumentasi data yang berkaitan dengan pengolahan data yang dilakukan sistem informasi perpustakaan yang sesuai dengan topik penelitian[5].

3. Instrumen

Instrumen dalam penelitian digunakan untuk mengumpulkan data, serta akan digunakan untuk melakukan pengukuran dengan tujuan menghasilkan data yang akurat, maka setiap instrumen harus memiliki skala. Skala yang digunakan dalam penelitian ini adalah skala Likert, skala Likert digunakan untuk mengukur sikap, pendapat dan persepsi seseorang atau selelompok orang tentang fenomena social. Pilihan terhadap masing-masing jawaban untuk tanggapan responden atas dimensi kualitas kepuasan diberi skor sebagai berikut: 
ILKOM Jurnal Ilmiah Volume 11 Nomor 2 Agustus 2019 Terakreditasi peringkat 3 SK. No. 28/E/KPT/2019

Tabel 1. Skala Likert [6]

\begin{tabular}{ccc}
\hline Pilihan Jawaban & Singkatan & Skor \\
\hline Sangat Setuju & SS & 5 \\
Setuju & S & 4 \\
Ragu-ragu & R & 3 \\
Tidak Setuju & TS & 2 \\
Sangat Tidak Setuju & STS & 1 \\
\hline
\end{tabular}

\section{Definisi Kepuasan}

Kepuasan adalah suatu keadaan yang dirasakan konsumen setelah mengalami suatu kinerja atau hasil yang telah memenuhi berbagai harapannya. Kepuasan adalah perasaan senang atau kecewa seseorang dari perbandingan antara kesannya terhadap kinerja atau hasil suatu produk dengan apa yang diharapkannya[7].

Kepuasan pengguna menggambarkan keselarasan antara harapan seseorang dan hasil yang diperoleh dengan adanya suatu sistem dimana tempat orang tersebut berpartisipasi dalam pengembangan sistem informasi. Kepuasan pengguna sistem informasi merupakan salah satu tolak ukur tingkat keberhasilan penerapan atau penggunaan sebuah sistem informasi, kepuasan tersebut merupakan penilaian yang menyangkut apakah kinerja suatu sistem informasi terbilang baik atau buruk, dan apakah sistem informasi yang digunakan cocok atau tidak dengan tujuan penggunanya.

\section{Definisi Kuesioner}

Angket atau kuesioner merupakan sejumlah pertanyaan atau pernyataan tertulis tentang data faktual atau opini yang berkaitan dengan diri responden, yang dianggap fakta atau kebenaran yang diketahui dan perlu dijawab oleh responden[8].

Kuesioner adalah salah satu alat pengumpul data dalam asesmen nontes, yang berupa serangkaian pertanyaan atau pernyataan yang diajukan pada responden (peserta didik, orang tua atau masyarakat). Angket dikenal dengan sebutan kuesioner. Secara garis besar terdiri dari tiga bagian yakni : (1) Judul angket, (2) Pengantar yang berisi tujuan atau cara pengisian angket dan (3) item item pertanyaan, bisa juga opini atau pendapat, dan fakta[9].

\section{PIECES Framework}

PIECES merupakan praktek pembelajaran terbaik dan inisiatif pengembangan yang menyediakan suatu pendekatan untuk memahami dan meningkatkan perawatan bagi individu dengan kebutuhan yang kompleks fisik dan kognitif serta perubahan perilaku[10]. PIECES memungkinkan dalam peningkatan perawatan bersama secara berkelanjutan melalui pengembangan sumber daya manusia. Dalam PIECES framework terdapat enam komponen yang dapat digunakan dalam evaluasi kepuasan pengguna sistem informasi[11]:

1. Performance (Kehandalan)

Kehandalan suatu sistem merupakan variabel pertama dari PIECES Framework dimana memiliki peran penting untuk melihat sejauh mana dan seberapa handal suatu sistem informasi dalam memproses atau mengolah data untuk menghasilkan informasi dan tujuan yang diharapkan.

Terdapat dua komponen yang harus diperhatikan sebagai acuan atau pedoman dalam mengevaluasi kinerja suatu sistem yaitu:

b. Apakah suatu sistem dapat atau mampu mengerjakan sejumlah perintah dalam periode waktu yang telah ditentukan dengan baik dan tanpa hambatan.

c. Sejauh mana kemampuan sebuah sistem dalam merespon suatu perintah maupun permintaan terhadap suatu transaksi apakah cepat atau lambat.

2. Information (Informasi dan Data)

Informasi dan data yang disajikan ataupun dibutuhkan oleh perusahaan merupakan salah satu faktor penting untuk kemajuan suatu perusahaan. Informasi yang dihasilkan sistem informasi harus benar-benar memiliki nilai yang berguna untuk pengambilan keputusan oleh manajemen perusahaan. Komponen yang diperhatikan dalam mengevaluasi sebuah sistem terkait data dan informasi yaitu:

a. Keluaran (Output), sejauh mana sebuah sistem dapat menghasilkan keluaran, terutama dalam menyajikan informasi yang dibutuhkan oleh perusahaan.

b. Masukan (Input), sejauh mana kehandalan sebuah sistem dalam memasukan data kemudian data tersebut diolah untuk menjadi sebuah informasi yang berguna bagi perusahaan.

c. Data yang disimpan (Stored Data), sejauh mana kehandalan sebuah sistem dalam menyimpan data kedalam media penyimpanan dan dalam mengakses data tersebut. 


\section{Economics (Nilai Ekonomis)}

Variabel economics menjadi suatu parameter apakah dengan pengorbanan perusahaan untuk mengaplikasikan sistem informasi perpustakaan yang saat ini digunakan sepadan dengan hasil yang diperoleh perusahaan.

Dalam segi ekonomi terdapat dua komponen yang diperhatikan dalam mengevaluasi sebuah sistem yaitu:

a. Biaya, merupakan evaluasi terhadap sejauh mana biaya yang dikeluarkan setelah perusahaan menggunakan atau menerapkan penggunaan sistem informasi.

b. Keuntungan, merupakan evaluasi apakah dalam penggunaan sistem informasi mampu memberikan keuntungan kepada perusahaan agar perusahaan dapat menuju ke arah yang lebih baik.

4. Control and Security (Pengamanan dan Pengendalian)

Sebaik-baiknya suatu sistem jika tidak disertai dengan pengendalian dan pengamanan yang baik, akan menjadi suatu sistem yang sangat lemah sehingga pihak dari luar sistem sangat mudah untuk masuk dan mengacaukan sistem tersebut. Oleh karena itu perlu adanya suatu pengendalian dan pengamanan terhadap suatu sistem informasi dengan memperhatikan hal - hal yang terkait pengendalian dan pengamanan sistem, yaitu:

a. Pengendalian dan pengamanan terhadap sistem terlalu lemah.

b. Pengendalian dan pengamanan terhadap sistem terlalu tinggi atau kompleks.

5. Efficiency (Efisiensi)

Sistem informasi yang digunakan secara mutlak harus memiliki nilai keunggulan jika dibandingkan dengan penggunaan sistem secara manual. Keunggulan tersebut terletak pada tingkat keefisienan saat sistem informasi tersebut beroperasi.

Acuan atau pedoman yang digunakan dalam menganalisis dan mengevaluasi suatu sistem dilihat dari segi keefisienannya jika dibandingkan pada saat penggunaan sistem manual, yaitu:

a. Karyawan, mesin atau computer dalam penggunaannya membuang waktu terlalu banyak atau pemborosan dalam penggunaan persediaan dan material perusahaan.

b. Dalam memenuhi tugas atau pekerjaan, apakah usaha yang diperlukan dalam menjalankan kegiatan menjadi terlalu berlebihan.

c. Pemenuhan kebutuhan material secara berlebihan hanya untuk menyelesaikan suatu tugas tertentu.

6. Service (Pelayanan)

Pelayanan terhadap konsumen sangatlah penting, pada penelitian ini yang dimaksud sebagai konsumen adalah pengguna sistem informasi perpustakaan. Kemajuan perusahaan juga ditentukan dari variabel ini, apakah para pengguna tersebut tertarik dan merasa puas dengan pelayanan yang dimiliki perusahaan, sehingga memungkinkan para pengguna untuk tidak beralih ke pesaing-pesaing bisnis yang lain. Oleh karena itu diperlukan beberapa hal yang dinilai penting dalam mempertahankan konsumen yang dimiliki perusahaan, yaitu:

a. Sistem harus dapat menghasilkan informasi yang dibutuhkan oleh pengguna dengan akurat.

b. Hasil yang diperoleh dari sebuah sistem haruslah konsisten.

c. Sistem yang diterapkan atau digunakan harus mudah dipelajari, dimengerti dan mudah untuk digunakan oleh pengguna, sehingga pengguna akan merasa nyaman dalam menggunakan sistem informasi tersebut.

d. Sistem harus bersifat fleksibel dan kompatibel.

\section{Hasil dan Pembahasan}

\subsection{Analisis Sistem}

Perpustakaan Utsman Bin Affan Universitas Muslim Indonesia (UMI) dalam memberikan layanan sirkulasi, layanan referensi, pencetakan label dan pengarsipan data buku sudah menggunakan beberapa aplikasi yang berbasis komputer. Aplikasi tersebut antara lain seperti aplikasi peminjaman buku, aplikasi pengembalian buku, aplikasi katalog pencarian buku dan lain lain. Berikut ini adalah tampilan dari sistem informasi perpustakaan Utsman Bin Affan: 
ILKOM Jurnal Ilmiah Volume 11 Nomor 2 Agustus 2019

Terakreditasi peringkat 3 SK. No. 28/E/KPT/2019

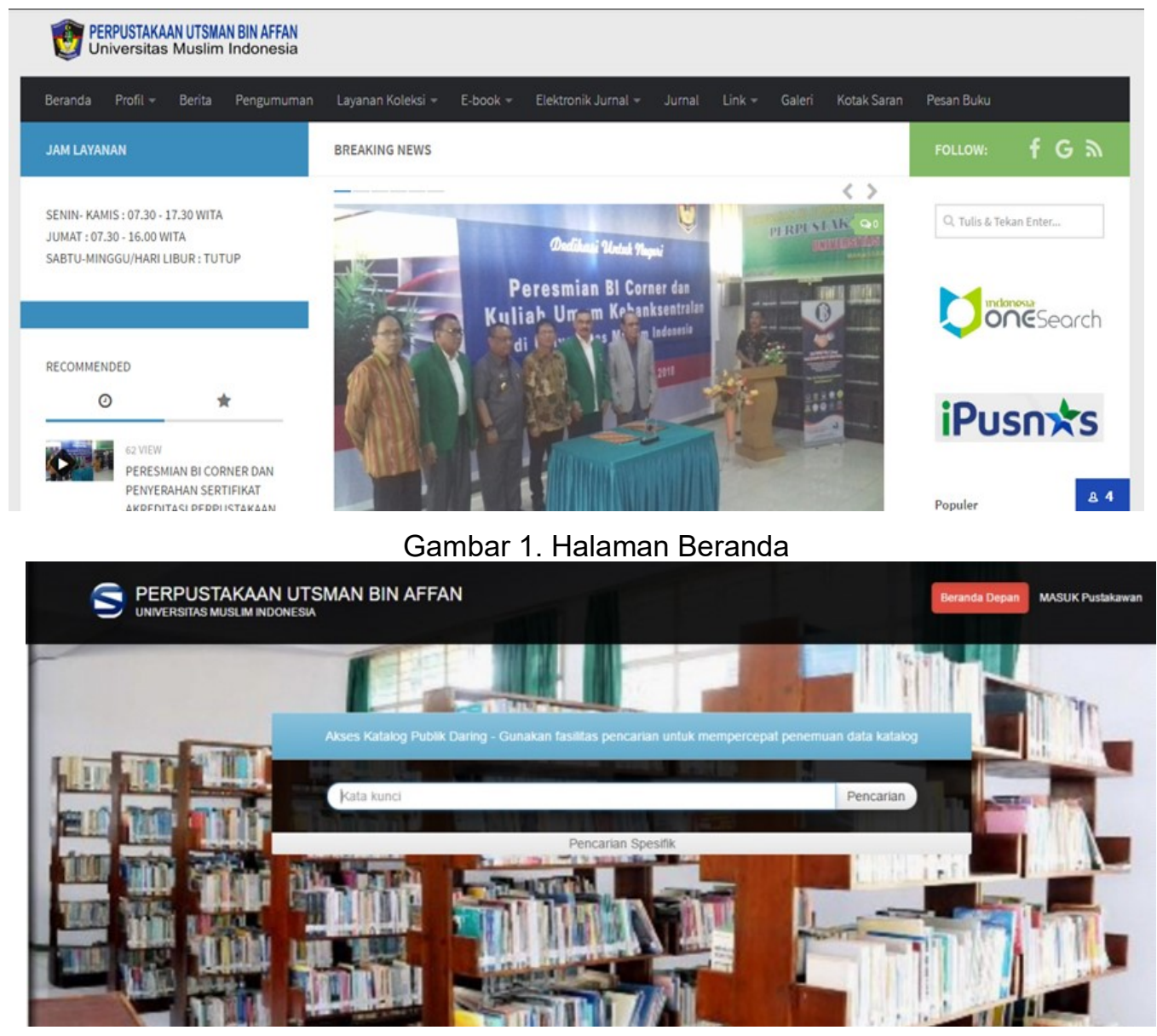

Gambar 2. Halaman OPAC (Online Public Access Catalog)

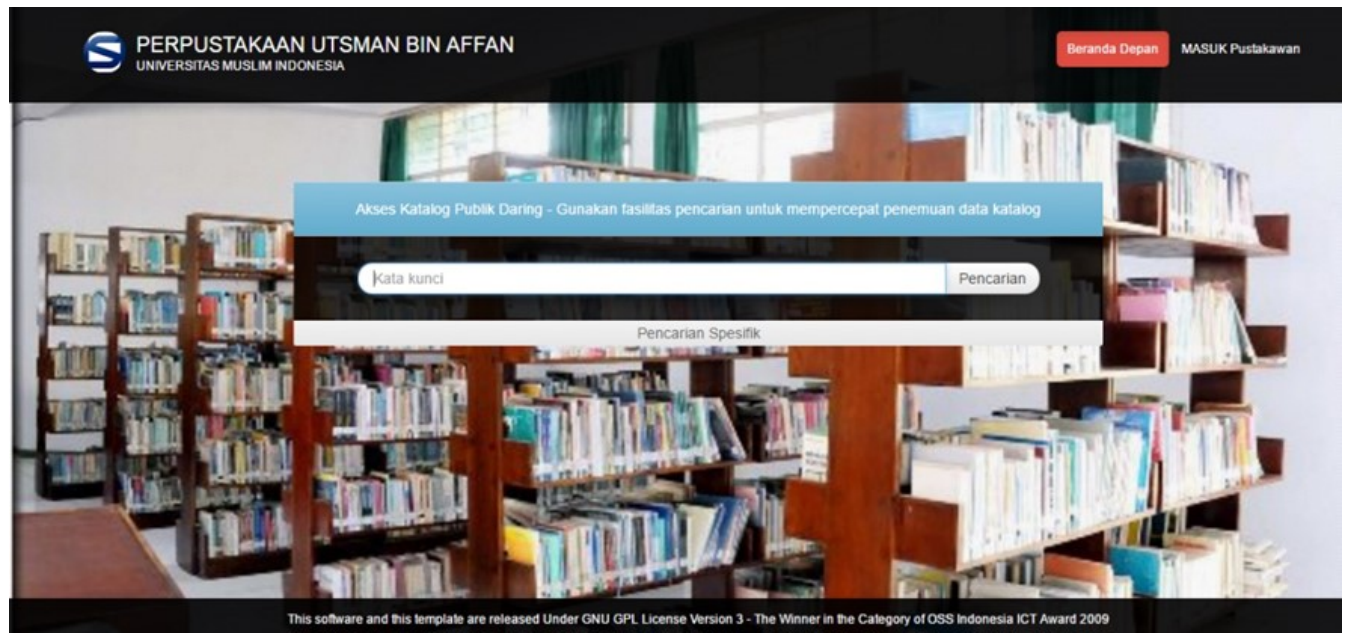

Gambar 3. Halaman Digital Library

\subsection{Hasil Perhitungan dan Analisa Data}

Berdasarkan hasil penyebaran kuesioner kepada 30 orang pengguna sistem informasi perpustakaan yang terdiri dari 20 orang mahasiswa dan 10 orang pustakawan, dengan menggunakan skala Likert untuk mengetahui tingkat kepuasan pengguna sistem informasi perpustakaan sesuai dengan pilihan jawaban dan skornya, maka untuk mendapatkan rata-rata tingkat kepuasan dengan menggunakan rumus:[12] 
ILKOM Jurnal Ilmiah Volume 11 Nomor 2 Agustus 2019

Terakreditasi peringkat 3 SK. No. 28/E/KPT/2019

$$
R K=\frac{J S K}{J K}
$$

RK = Rata-Rata Kepuasan

JSK = Jumlah Skor Kuesioner

$\mathrm{JK}=$ Jumlah Kuesioner

Sedangkan untuk menentukan tingkat kepuasan menggunakan model yang didefinisikan oleh Kaplan dan Norton dengan tingkatan sebagai berikut :[13]

$$
\begin{array}{ll}
1-1.79 & =\text { Sangat Tidak Puas } \\
1.8-2.59 & =\text { Tidak Puas } \\
2.6-3.3 & =\text { Ragu-Ragu } \\
3.4-4.91 & =\text { Puas } \\
4.92-5 & =\text { Sangat Puas }
\end{array}
$$

\begin{tabular}{|c|c|}
\hline No. & Pernyataan \\
\hline 1. & Sistem informasi perpustakaan sangat mudah diakses oleh pengguna \\
\hline 2. & $\begin{array}{l}\text { Sistem informasi perpustakaan dapat mengoperasikan sejumlah perintah dalam waktu } \\
\text { yang relatif singkat, tanpa mengalami hambatan }\end{array}$ \\
\hline 3. & $\begin{array}{l}\text { Sistem informasi perpustakaan dalam merespons suatu perintah pembatalan maupun } \\
\text { permintaan terhadap suatu transaksi dilakukan dengan cepat }\end{array}$ \\
\hline 4. & $\begin{array}{l}\text { Jumlah data yang dapat diproses sistem informasi perpustakaan pada satuan waktu } \\
\text { sudah sesuai dengan yang diharapkan }\end{array}$ \\
\hline 5. & $\begin{array}{l}\text { Pada saat sistem informasi perpustakaan digunakan secara bersamaan, kinerja sistem } \\
\text { informasi tetap berjalan stabil }\end{array}$ \\
\hline 6. & $\begin{array}{l}\text { Total waktu yang dibutuhkan dalam melakukan pengolahan data hingga menghasilkan } \\
\text { informasi sudah dilakukan dengan cepat }\end{array}$ \\
\hline
\end{tabular}

Dengan penentuan tingkat kepuasan seperti diatas, diperoleh rata-rata tingkat kepuasan pengguna petugas perpustakaan berdasarkan domain yang terdapat pada PIECES Framework adalah sebagai berikut:

\section{Performance}

Tabel 2. Kuesioner Domain Performance

Tabel 3. Tabulasi Kuesioner Domain Performance

\begin{tabular}{cccccc}
\hline \multicolumn{7}{c}{ PERFORMANCE } \\
\hline RESPONDEN & SS & S & RR & TS & STS \\
SKOR & 5 & 4 & 3 & 2 & 1 \\
R1 & 1 & 3 & 0 & 2 & 0 \\
R2 & 2 & 3 & 1 & 0 & 0 \\
R3 & 3 & 3 & 0 & 0 & 0 \\
R4 & 0 & 4 & 2 & 0 & 0 \\
R5 & 6 & 0 & 0 & 0 & 0 \\
R6 & 6 & 0 & 0 & 0 & 0 \\
R7 & 5 & 1 & 0 & 0 & 0 \\
R8 & 0 & 5 & 1 & 0 & 0 \\
R9 & 2 & 4 & 0 & 0 & 0 \\
R10 & 3 & 3 & 0 & 0 & 0 \\
JUMLAH & 28 & 26 & 4 & 2 & 0 \\
\hline
\end{tabular}

$$
\begin{aligned}
& R K=\frac{(5 * 28)+(4 * 26)+(3 * 4)+(2 * 2)+(1 * 0)}{60} \\
& R K=4.33
\end{aligned}
$$

Berdasarkan hasil perhitungan jumlah rata-rata tingkat kepuasan diperoleh nilai 4.33 pada domain kinerja sistem dan bila dipadukan dengan tingkat kepuasan menurut Kaplan dan Norton, 
ILKOM Jurnal Ilmiah Volume 11 Nomor 2 Agustus 2019

Terakreditasi peringkat 3 SK. No. 28/E/KPT/2019

maka dapat disimpulkan bahwa tingkat kepuasan pengguna terhadap sistem informasi perpustakaan termasuk dalam kategori Puas.

\section{Informations and Data}

Tabel 4. Kuesioner Domain Informations and Data

\begin{tabular}{cl}
\hline No. & \multicolumn{1}{c}{ Pernyataan } \\
\hline 1. & Data yang disimpan oleh sistem informasi perpustakaan sudah tersimpan sesuai \\
2. Sengan yang dimasukkan ke dalam sistem & Sistem informasi perpustakaan tidak dapat menyimpan data yang bukan seharusnya \\
3. Data yang mengandung kesalahan atau data yang tidak benar tidak dapat disimpan \\
oleh sistem informasi perpustakaan
\end{tabular}

Tabel 5. Tabulasi Kuesioner Domain Informations and Data

\begin{tabular}{|c|c|c|c|c|c|}
\hline \multicolumn{6}{|c|}{ PERFORMANCE } \\
\hline RESPONDEN & SS & $\mathrm{S}$ & RR & TS & STS \\
\hline SKOR & 5 & 4 & 3 & 2 & 1 \\
\hline R1 & 0 & 5 & 0 & 0 & 0 \\
\hline R2 & 0 & 2 & 3 & 0 & 0 \\
\hline R3 & 2 & 3 & 0 & 0 & 0 \\
\hline R4 & 0 & 3 & 1 & 1 & 0 \\
\hline R5 & 3 & 2 & 0 & 0 & 0 \\
\hline R6 & 4 & 1 & 0 & 0 & 0 \\
\hline R7 & 3 & 2 & 0 & 0 & 0 \\
\hline R8 & 0 & 4 & 1 & 0 & 0 \\
\hline R9 & 1 & 2 & 1 & 1 & 0 \\
\hline R10 & 0 & 1 & 4 & 0 & 0 \\
\hline JUMLAH & 13 & 25 & 10 & 2 & 0 \\
\hline \multicolumn{6}{|c|}{$(5 * 13)+(4 * 25)+(3 * 10)+(2 * 2)+(1 * 0)$} \\
\hline \multicolumn{6}{|c|}{$\begin{array}{l}50 \\
\end{array}$} \\
\hline
\end{tabular}

Berdasarkan hasil perhitungan jumlah rata-rata tingkat kepuasan diperoleh nilai 3.98 pada domain data dan informasi dan bila dipadukan dengan tingkat kepuasan menurut Kaplan dan Norton, maka dapat disimpulkan bahwa tingkat kepuasan pengguna terhadap sistem informasi perpustakaan termasuk dalam kategori Puas.

\section{Economics}

Tabel 6. Kuesioner Domain Economics

\begin{tabular}{cl}
\hline No. & \multicolumn{1}{c}{ Pernyataan } \\
\hline 1. & $\begin{array}{l}\text { Biaya yang dikeluarkan oleh perpustakaan menjadi lebih ringan dengan adanya sistem } \\
\text { informasi perpustakaan dibandingkan dengan menggunakan cara konvensional. }\end{array}$ \\
2. & $\begin{array}{l}\text { Pada saat pembangunan dan penerapan sistem informasi perpustakaan, biaya yang } \\
\text { dikeluarkan perusahaan cukup tinggi. }\end{array}$ \\
3. Ada perubahan yang signifikan dalam hal perkembangan dan pertumbuhan dengan \\
adanya sistem informasi perpustakaan
\end{tabular}

Tabel 7. Tabulasi Kuesioner Domain Economics

\begin{tabular}{cccccc}
\hline \multicolumn{7}{c}{ PERFORMANCE } \\
\hline RESPONDEN & SS & S & RR & TS & STS \\
SKOR & $\mathbf{5}$ & $\mathbf{4}$ & $\mathbf{3}$ & $\mathbf{2}$ & $\mathbf{1}$ \\
R1 & 0 & 3 & 0 & 0 & 0
\end{tabular}

DOI: http://dx.doi.org/10.33096/ilkom.v11i2.398.118-128

ILKOM Jurnal IImiah work is licensed under a CCA-SA 4.0 International License. | 124 
ILKOM Jurnal Ilmiah Volume 11 Nomor 2 Agustus 2019

Terakreditasi peringkat 3 SK. No. 28/E/KPT/2019

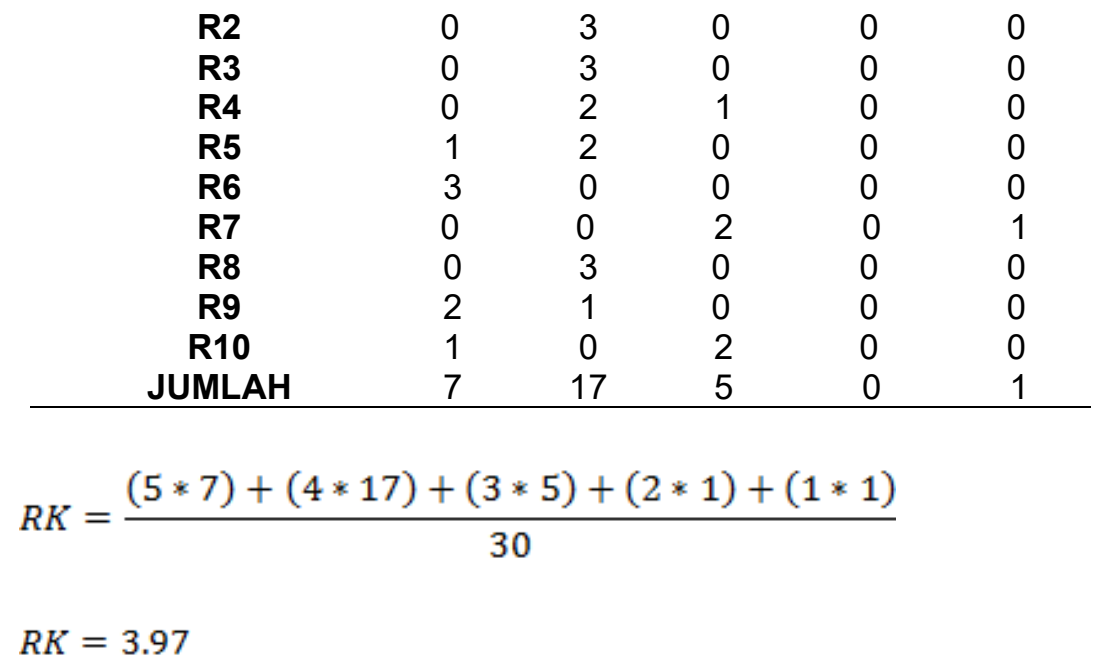

Berdasarkan hasil perhitungan jumlah rata-rata tingkat kepuasan diperoleh nilai 3.97 pada domain ekonomi dan bila dipadukan dengan tingkat kepuasan menurut Kaplan dan Norton, maka dapat disimpulkan bahwa tingkat kepuasan pengguna terhadap sistem informasi perpustakaan termasuk dalam kategori Puas.

\section{Control and Security}

Tabel 8. Kuesioner Domain Control and Security

\begin{tabular}{cl}
\hline No. & \multicolumn{1}{c}{ Pernyataan } \\
\hline 1. & Bentuk pengamanan yang terdapat pada sistem informasi perpustakaan sudah dapat \\
2. & Sistem pengamanan pada sistem informasi sudah baik. \\
3. Manajemen dalam memberikan otorisasi dan menentukan pengendalian akses \\
4. Merhadap penggunaan dan pengoperasian sistem sudah jelas. \\
5. Media penyimpanan aman dari perusakan dan kecelakaan. \\
\hline
\end{tabular}

Tabel 9. Tabulasi Kuesioner Domain Control and Security

\begin{tabular}{cccccc}
\hline \multicolumn{7}{c}{ PERFORMANCE } \\
\hline RESPONDEN & SS & S & RR & TS & STS \\
SKOR & $\mathbf{5}$ & $\mathbf{4}$ & $\mathbf{3}$ & $\mathbf{2}$ & $\mathbf{1}$ \\
R1 & 0 & 2 & 3 & 0 & 0 \\
R2 & 0 & 5 & 0 & 0 & 0 \\
R3 & 0 & 5 & 0 & 0 & 0 \\
R4 & 0 & 5 & 0 & 0 & 0 \\
R5 & 3 & 2 & 0 & 0 & 0 \\
R6 & 5 & 0 & 0 & 0 & 0 \\
R7 & 0 & 5 & 0 & 0 & 0 \\
R8 & 0 & 4 & 1 & 0 & 0 \\
R9 & 0 & 5 & 0 & 0 & 0 \\
R10 & 0 & 3 & 2 & 0 & 0 \\
JUMLAH & 8 & 36 & 6 & 0 & 0 \\
\hline
\end{tabular}

$$
\begin{aligned}
& R K=\frac{(5 * 8)+(4 * 36)+(3 * 6)+(2 * 0)+(1 * 0)}{50} \\
& R K=4.04
\end{aligned}
$$


ILKOM Jurnal Ilmiah Volume 11 Nomor 2 Agustus 2019

Terakreditasi peringkat 3 SK. No. 28/E/KPT/2019

Berdasarkan hasil perhitungan jumlah rata-rata tingkat kepuasan diperoleh nilai 4.04 pada domain pengendalian dan keamanan dan bila dipadukan dengan tingkat kepuasan menurut Kaplan dan Norton, maka dapat disimpulkan bahwa tingkat kepuasan pengguna terhadap sistem informasi perpustakaan termasuk dalam kategori Puas.

\section{Efficiency}

\begin{tabular}{cc}
\hline No. & \multicolumn{1}{c}{ Pernyataan } \\
\hline 1. & $\begin{array}{l}\text { Sistem yang digunakan sekarang lebih meringankan pengguna baik dari segi biaya dan } \\
\text { waktu }\end{array}$ \\
2. Dalam mengoperasikan sistem pada kegiatan/aktivitas perpustakaan sehari-hari, sistem \\
dapat menghasilkan output yang sesuai dengan waktu dan material yang minimal.
\end{tabular}

Tabel 11. Tabulasi Kuesioner Domain Efficiency

\begin{tabular}{cccccc}
\hline \multicolumn{7}{c}{ PERFORMANCE } \\
\hline RESPONDEN & SS & S & RR & TS & STS \\
SKOR & $\mathbf{5}$ & $\mathbf{4}$ & $\mathbf{3}$ & $\mathbf{2}$ & $\mathbf{1}$ \\
R1 & 0 & 2 & 0 & 0 & 0 \\
R2 & 0 & 2 & 0 & 0 & 0 \\
R3 & 0 & 2 & 0 & 0 & 0 \\
R4 & 0 & 2 & 0 & 0 & 0 \\
R5 & 2 & 0 & 0 & 0 & 0 \\
R6 & 2 & 0 & 0 & 0 & 0 \\
R7 & 1 & 1 & 0 & 0 & 0 \\
R8 & 1 & 1 & 0 & 0 & 0 \\
R9 & 1 & 1 & 0 & 0 & 0 \\
R10 & 2 & 0 & 0 & 0 & 0 \\
JUMLAH & 9 & 11 & 0 & 0 & 0 \\
\hline \multicolumn{7}{c}{20} \\
(5 * 9) $+(4 * 11)+(3 * 0)+(2 * 0)+(1 * 0)$ & \\
$R K=4.45$ & \multicolumn{7}{c}{}
\end{tabular}

Berdasarkan hasil perhitungan jumlah rata-rata tingkat kepuasan diperoleh nilai 4.45 pada domain efisiensi dan bila dipadukan dengan tingkat kepuasan menurut Kaplan dan Norton, maka dapat disimpulkan bahwa tingkat kepuasan pengguna terhadap sistem informasi perpustakaan termasuk dalam kategori Puas.

\section{Service}

Tabel 12. Kuesioner Domain Service

\begin{tabular}{cl}
\hline No. & \multicolumn{1}{c}{ Pernyataan } \\
\hline 1. & Sistem informasi perpustakaan mudah digunakan \\
2. & Sistem informasi perpustakaan fleksibel jika digunakan untuk situasi yang baru \\
3. & Sistem informasi perpustakaan dapat dirubah secara fleksibel \\
4. & Sistem informasi perpustakaan dapat memberikan kepuasan anda sebagai \\
\hline
\end{tabular}

Tabel 13. Tabulasi Kuesioner Domain Service

\begin{tabular}{cccccc}
\hline \multicolumn{7}{c}{ PERFORMANCE } \\
\hline RESPONDEN & SS & S & RR & TS & STS \\
SKOR & $\mathbf{5}$ & $\mathbf{4}$ & $\mathbf{3}$ & $\mathbf{2}$ & $\mathbf{1}$ \\
R1 & 0 & 4 & 0 & 0 & 0 \\
R2 & 0 & 4 & 0 & 0 & 0 \\
R3 & 0 & 4 & 0 & 0 & 0 \\
R4 & 0 & 4 & 0 & 0 & 0
\end{tabular}


ILKOM Jurnal Ilmiah Volume 11 Nomor 2 Agustus 2019

Terakreditasi peringkat 3 SK. No. 28/E/KPT/2019

\begin{tabular}{cccccc}
$\mathbf{R} 5$ & 3 & 1 & 0 & 0 & 0 \\
$\mathbf{R 6}$ & 3 & 1 & 0 & 0 & 0 \\
$\mathbf{R 7}$ & 2 & 2 & 0 & 0 & 0 \\
$\mathbf{R 8}$ & 1 & 3 & 0 & 0 & 0 \\
$\mathbf{R 9}$ & 0 & 4 & 0 & 0 & 0 \\
$\mathbf{R} 10$ & 4 & 0 & 0 & 0 & 0 \\
JUMLAH & 13 & 27 & 0 & 0 & 0 \\
\hline \\
$R K=\frac{(5 * 13)+(4 * 27)+(3 * 0)+(2 * 0)+(1 * 0)}{40}$ \\
$R K=4.33$
\end{tabular}

Berdasarkan hasil perhitungan jumlah rata-rata tingkat kepuasan diperoleh nilai 4.33 pada domain layanan dan bila dipadukan dengan tingkat kepuasan menurut Kaplan dan Norton, maka dapat disimpulkan bahwa tingkat kepuasan pengguna terhadap sistem informasi perpustakaan termasuk dalam kategori Puas.

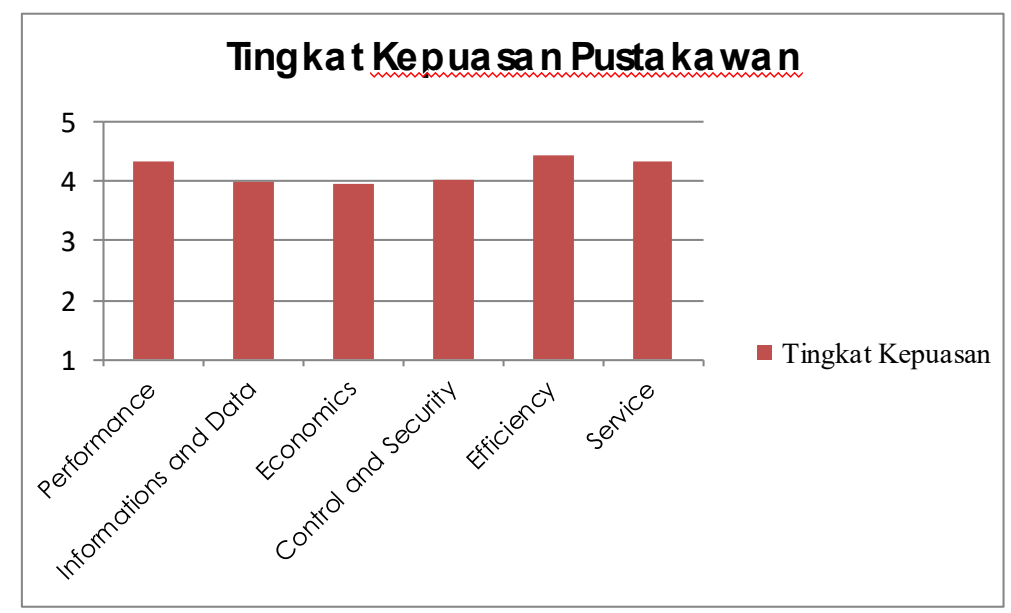

Gambar 4. Grafik Tingkat Kepuasan Pustakawan

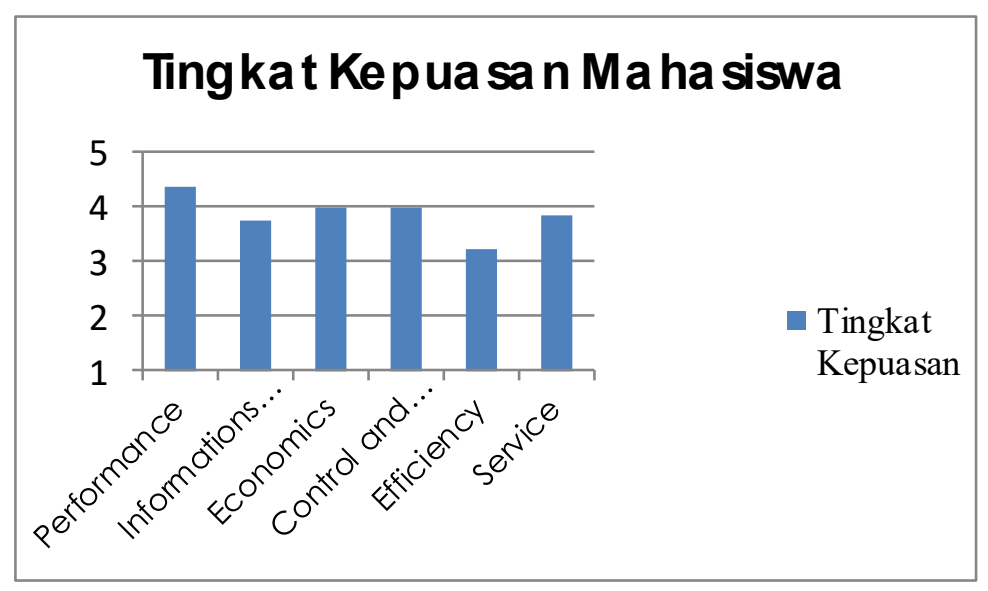

Gambar 5. Grafik Tingkat Kepuasan Mahasiswa 
ILKOM Jurnal Ilmiah Volume 11 Nomor 2 Agustus 2019 Terakreditasi peringkat 3 SK. No. 28/E/KPT/2019

\section{Kesimpulan dan Saran}

Berdasarkan metode analisis kerangka kerja PIECES dalam mengevaluasi sistem informasi perpustakaan didapatkan nilai tingkat kepuasan responden Pustakawan dari masing-masing domain yaitu domain Performance memperoleh skor 4.33 dengan predikat PUAS, domain Information and Data memperoleh skor 3.98 dengan predikat PUAS, domain Economics memperoleh skor 3.97 dengan predikat PUAS, domain Control and Security memperoleh skor 4.04 dengan predikat PUAS, domain Efficiency memperoleh skor 4.45 dengan predikat PUAS dan domain Service memperoleh skor 4.33 dengan predikat PUAS. Berdasarkan metode analisis kerangka kerja PIECES dalam mengevaluasi sistem informasi perpustakaan didapatkan nilai tingkat kepuasan responden Mahasiswa dari masing-masing domain yaitu domain Performance memperoleh skor 4.38 dengan predikat PUAS, domain Information and Data memperoleh skor 3.75 dengan predikat PUAS, domain Economics memperoleh skor 4.00 dengan predikat PUAS, domain Control and Security memperoleh skor 4.00 dengan predikat PUAS, domain Efficiency memperoleh skor 3.25 dengan predikat RAGURAGU dan domain Service memperoleh skor 3.85 dengan predikat PUAS. Sistem informasi perpustakaan berdasarkan kerangka kerja PIECES sudah mampu memberikan kepuasan kepada pengguna. Kerangka kerja PIECES dapat digunakan untuk menganalisa tingkat kepuasan pengguna atas sistem informasi yang digunakan.

\section{Daftar Pustaka}

[1] F. R. Fauzan Erlangi, "Sistem Informasi Perpustakaan Terpusat Pada Perpustakaan Daerah Se-Kabupaten Bandung Barat,” pp. 171-177, 2017.

[2] Betara Indra G Hendra, "Jaringan Lapan Bandung Menggunakan Metode Pieces," 2013.

[3] Sugiyono, Metode penelitian pendidikan:(pendekatan kuantitatif, kualitatif dan $R$ \& $D$ ). Bandung: Alfabeta, 2008.

[4] Sugiyono, Statistika untuk penelitian. Bandung: CV. Alfabeta, 2007.

[5] Albi Anggito \& Johan Setiawan, Metodologi penelitian kualitatif. Sukabumi: CV Jejak, 2018.

[6] A. Supriyatna and J. M. Informatika, "Perpustakaan Dengan Menggunakan Pieces Framework," vol. XI, no. 1, pp. 43-52, 2015.

[7] Kotler, "Marketing Management Millenium Edition.pdf." 11 Th Edition/International Edition Pretice Hall, New Jersey, 2003.

[8] A. Sutoyo, Pemahaman Individu (Observasi, Checklist, Interviu, Kuesioner, Sosiometri). Pustaka Pelajar, 2009.

[9] Sugiyono, Metode Penelitian Pendidikan Pendekatan Kuantitatif, Kualitatif, dan R\&D. Bandung: Alfabeta, 2014.

[10] P. Tingkat, K. Mahasiswa, and D. Penggunaan, "PARADIGMA Vol. XVIII. No.2 September 2016," vol. XVIII, no. 2, pp. 81-88, 2016.

[11] R. S. Dewi, R. R. Marchada, and A. Rifai, "Analisa Pieces Penerapan Digital Monitoring Informasi Penyewaan Ruko Pasar 8 Pada Pt . Alam Sutera Realty, Tbk," Semin. Nas. Teknol. Inf. dan Komun. 2016 (SENTIKA 2016), vol. 2016, no. Sentika, pp. 18-19, 2016.

[12] S. A. WIBOWO, "Evaluasi Sistem Administrasi Akademik Mahasiswa Perguruan Tinggi Dengan Menggunakan Metode Analisis Pieces Framework," 2005.

[13] A. Supriyatna and V. Maria, "Pengukuran Tingkat Kepuasan Pengguna Sistem Informasi Djp Online Pelaporan Spt Pajak," Pros. SNATIF, vol. 0, no. 0, pp. 147-154, 2017. 